\title{
Regulatory responses of Methanosarcina barkeri to freezing temperatures and perchlorates: Transcriptomic insights into the potential for biological Martian methanogenesis
}

Rachel Harris ( $\square$ rachel_harris@fas.harvard.edu )

Harvard University

Andrew Schuerger

University of Florida

Wei Wang

Princeton University

Yuri Tamama

Princeton University

Zachary Garvin

Princeton University

Tullis Onstott

Princeton University

\section{Research Article}

Keywords: Methanogens, transcriptomics, perchlorates, astrobiology, Mars

Posted Date: February 22nd, 2021

DOI: https://doi.org/10.21203/rs.3.rs-247246/v1

License: (c) (i) This work is licensed under a Creative Commons Attribution 4.0 International License.

Read Full License 


\section{Abstract}

Observations of trace methane $(\mathrm{CH} 4)$ in the Martian atmosphere are significant to the astrobiology community given the overwhelming contribution of biological methanogenesis to atmospheric $\mathrm{CH} 4$ on Earth. Previous studies have shown that methanogenic Archaea can generate $\mathrm{CH} 4$ when incubated with perchlorates, highly oxidizing chaotropic salts which have been found across the Martian surface. However, the regulatory mechanisms behind this remain completely unexplored. In this study we performed comparative transcriptomics on the methanogen Methanosarcina barkeri, which was incubated at $30^{\circ} \mathrm{C}$ and $0^{\circ} \mathrm{C}$ with $10 \mathrm{mM}$ calcium-, magnesium-, or sodium perchlorate. Consistent with prior studies, we observed decreased $\mathrm{CH} 4$ production and apparent perchlorate reduction, with the latter process proceeding by heretofore essentially unknown mechanisms. Transcriptomic responses of $\mathrm{M}$. barkeri to perchlorates include up-regulation of osmoprotectant transporters and selection against redoxsensitive amino acids. Regulatory switches to methylamines for methanogenesis suggest competition for $\mathrm{H} 2$ with perchlorate reduction, which we propose is catalyzed by up-regulated molybdenum-containing enzymes and maintained by siphoning diffused $\mathrm{H} 2$ from energy-conserving hydrogenases.

Methanogenesis regulatory patterns suggest Mars' freezing temperatures alone pose greater constraints to $\mathrm{CH} 4$ production than perchlorates. These findings increase our understanding of potential methanogen survival beyond Earth and a biological contribution to Martian $\mathrm{CH} 4$.

\section{Introduction}

The story of Martian atmospheric methane $\left(\mathrm{CH}_{4}\right)$ remains enigmatic and under intense debate. In the past 15 years, a growing body of evidence has unfolded to suggest episodic appearances (and disappearances) of ppbv-level $\mathrm{CH}_{4}{ }^{1-7}$. Myriad abiotic mechanisms have been suggested as potential $\mathrm{CH}_{4}$ sources, including cometary impacts ${ }^{8}$, UV degradation of meteoritic and interplanetary dust particle organics $^{9-11}$, and Fischer-Tropsch-type synthesis in the subsurface coupled to either serpentinization of ultramafic silicates ${ }^{12,13}$ or radiolysis of $\mathrm{H}_{2} \mathrm{O}^{14}$, which subsequently releases $\mathrm{CH}_{4}$ to the surface through seeps and salinity-induced hydrate dissociation ${ }^{15}$ (Fig. 1). On Earth, however, nearly $70 \%$ of $\mathrm{CH}_{4}$ is of biological origin, generated by methanogenic Archaea ${ }^{16}$. This has led to an extensive debate considering the biological origin of Martian $\mathrm{CH}_{4}$. Understandably, the quest to comprehend the nature of $\mathrm{CH}_{4}$ cycling on Mars is a fervent one, as it may be the most conspicuous biosignature detected on Mars to date. In the absence of returned Martian samples or stable isotopic data of Martian atmospheric $\mathrm{CH}_{4}$, presently the best approach to constrain this debate is to experimentally test the ability of methanogenic Archaea to metabolize under Martian conditions.

Methanogens are not only among the most deeply rooted microorganisms in the tree of life, but they have also proliferated into nearly every habitable anaerobic environment and possess conserved adaptions for growth and survival under exposure to prolonged desiccation ${ }^{17-19}$, high salinity ${ }^{20-24}$, strong oxidants $^{25,26}$, and extremes in temperature, $\mathrm{pH}$, and pressure ${ }^{27-31}$. Thus, they have been the subject of 
extensive study to infer how hostile conditions simulating modern Mars may allow - or inhibit biological methanogenesis ${ }^{17,19,25,26,31-34}$.

Perchlorate salts are highly soluble, chaotropic compounds that appear to be pervasive on Mars ${ }^{35-41}$. Perchlorates are of great interest to Martian habitability studies for their hygroscopicity and low eutectic temperatures, allowing for the formation of stable liquid water brines at temperatures as low as $-74.6^{\circ} \mathrm{C}$

and $55 \%$ relative humidity ${ }^{42-47}$. Previous work has reported decreased $\mathrm{CH}_{4}$ production in methanogenic cultures supplemented with increasing concentrations of perchlorate salts ${ }^{25,26}$. This suggests that this aspect of the Martian environment may be debilitating to biological methanogenesis, but the mechanisms resulting in this apparent inhibition have not been identified. Here we utilize transcriptomics to evaluate regulatory responses of the methanogenic archaeon Methanosarcina barkeri strain MS during a 28-day exposure to high concentrations of sodium-, magnesium-, and calcium perchlorate salts at $30^{\circ} \mathrm{C}$ and $0^{\circ} \mathrm{C}$ to assess if perchlorate salts are inhibitory to methanogenesis - and if so, how - in order to appraise the potential for methanogens' survival on Mars.

\section{Results}

\section{Transcriptome assembly statistics}

M. barkeri possesses the second largest described genome amongst the methanogenic Archaea ${ }^{48}$. This genome comprises a 4.53 megabase $(\mathrm{Mb})$ circular chromosome and a 40 kilobase $(\mathrm{kb})$ plasmid, which collectively encode 3,760 genes, 3,470 of which are protein-encoding coding sequence (CDS) regions (3.17 Mb). RNA sequencing yielded a total of 1,500,716,043 quality paired end reads across 24 libraries (8 conditions $\times 3$ replicates/condition) with a mean Phred (sequence quality) score of 36 . On average $1.6 \pm$ $0.7 \%$ of $30^{\circ} \mathrm{C}$ and $1.5 \pm 0.5 \%$ of $0^{\circ} \mathrm{C}$ quality-filtered reads mapped back to CDS regions ( $n=12$ libraries/temperature condition; Table S1), consistent with expectations that mRNA typically comprises 1$5 \%$ of total RNA in prokaryotic cells ${ }^{49}$. Average fragment counts per million mapped reads (FPM) are organized by gene position in Table S2 and visualized in Figs. S1-S2.

\section{Methanogenesis and associated regulatory responses}

At $30^{\circ} \mathrm{C}$, the addition of $\mathrm{Ca}\left(\mathrm{ClO}_{4}\right)_{2}, \mathrm{Mg}\left(\mathrm{ClO}_{4}\right)_{2}$, and $\mathrm{Na}\left(\mathrm{ClO}_{4}\right)$ reduced total net $\mathrm{CH}_{4}$ production by $48 \%$, $32 \%$, and $24 \%$, respectively, relative to the perchlorate-free control (Fig. 2). Significant reduction in $\mathrm{CH}_{4}$ production rates were observed across all conditions at $0^{\circ} \mathrm{C}$ with respect to their $30^{\circ} \mathrm{C}$ counterparts, and each perchlorate condition at $0^{\circ} \mathrm{C}$ showed a statistically significant decrease in $\mathrm{CH}_{4}$ for at least one time point relative to the $0^{\circ} \mathrm{C}$ control (Fig. 2). $\mathrm{No}^{\mathrm{CH}_{4}}$ production was observed in the media blank controls (data not shown). Cultures were monitored via optical density measurements at $600 \mathrm{~nm}\left(\mathrm{OD}_{600}\right)$, but perchlorate-amended media experienced precipitate formation which made obtaining reliable growth data difficult (Fig. S3). 
When incubated at $0^{\circ} \mathrm{C}$, the perchlorate-free control demonstrated significant up-regulation of several genes in the hydrogenotrophic pathway relative to the $30^{\circ} \mathrm{C}$ perchlorate-free control (Table 1, Fig. 3 ), including $\log _{2}$-fold changes (LFC) in molybdenum (Mo)-formylmethanofuran dehydrogenase subunit $B$ $(f m d B)$, methenyl-tetrahydrosarcinapterin $\left(\mathrm{H}_{4} \mathrm{SPT}\right)$ cyclohydrolase $(m c h)$, and periplasmic heterodisulphide reductase ( $h d r D E)$. Likewise, significant down-regulation was observed in the sodium ion $\left(\mathrm{Na}^{+}\right)$transporter methyl- $\mathrm{H}_{4} \mathrm{SPT}$ :coenzyme $\mathrm{M}$ methyltransferase complex $(\mathrm{mtrA})$, as well as the $\mathrm{F}_{420^{-}}$ reducing subunit of the periplasmic energy conserving hydrogenase (echF). All subunits of both coenzyme $\mathrm{F}_{420}$ hydrogenases (frhabg) were significantly up-regulated in perchlorate-free $0^{\circ} \mathrm{C}$ incubations (Table 1, Fig. 3). In the perchlorate-treated incubations at $0^{\circ} \mathrm{C}$, we only observed down-regulation of frhabg in the presence of $\mathrm{Ca}\left(\mathrm{ClO}_{4}\right)_{2}$ with respect to the $0^{\circ} \mathrm{C}$ perchlorate-free control (Table 2, Fig. 3).

At $30^{\circ} \mathrm{C}$, methanogenesis-associated regulatory responses were shared across all perchlorate conditions (Table 1). This included up-regulation of $B, C$, and $D$ subunits of (Mo)-formylmethanofuran dehydrogenase, fmd, which catalyzes the $\mathrm{CO}_{2}$ reduction step of the hydrogenotrophic pathway (Fig. 3). In the presence of both $\mathrm{Mg}\left(\mathrm{ClO}_{4}\right)_{2}$ and $\mathrm{Na}\left(\mathrm{ClO}_{4}\right)$, one copy of (Mo)-fmdE exhibited significant up-regulation, while the other was significantly down-regulated (Table 1). Unique to the $\mathrm{Mg}\left(\mathrm{ClO}_{4}\right)_{2}$ incubations was the up-regulation of tungsten (W)-fmdA. In contrast, perchlorate-supplemented treatments incubated at $0^{\circ} \mathrm{C}$ demonstrated statistically significant down-regulation of Mo-fmd genes, but up-regulation of the (W)-fmd operon (Table 2).

Energy conserving hydrogenase subunit $\mathrm{F}$, echF, which supplies reduced ferredoxin to $f m d$, was downregulated in the presence of $\mathrm{Mg}\left(\mathrm{ClO}_{4}\right)_{2}$ and $\mathrm{Na}\left(\mathrm{ClO}_{4}\right)$ at $30^{\circ} \mathrm{C}$, whereas most subunits of ech were significantly up-regulated in $30^{\circ} \mathrm{C} \mathrm{Ca}\left(\mathrm{ClO}_{4}\right)_{2}$ conditions (Fig. 3). Among other hydrogenases demonstrating significant up-regulation was methanophenazine-dependent hydrogenase, $v h t$, specifically, the large subunit $v h t \mathrm{~A}$ and cytochrome $\mathrm{b}$ subunit vhtC (Fig. 3). At $0^{\circ} \mathrm{C}$, ech hydrogenases were not differentially regulated in the presence of perchlorates relative to the perchlorate-free control (Fig. 3).

Despite $\mathrm{H}_{2}$ being the only reducing equivalent provided for the production of $\mathrm{CH}_{4}$ in our incubations, the addition of $\mathrm{Ca}\left(\mathrm{ClO}_{4}\right)_{2}, \mathrm{Mg}\left(\mathrm{ClO}_{4}\right)_{2}$, and $\mathrm{Na}\left(\mathrm{ClO}_{4}\right)$ resulted in significant up-regulation of all genes in the mono-, di-, and trimethylamine pathways and associated membrane permeases in the $30^{\circ} \mathrm{C}$ perchlorate treatments (Fig. 3, Tables S6, S8, S10).

The terminal step encoding methyl-coenzyme $\mathrm{M}\left(\mathrm{CH}_{3}-\mathrm{CoM}\right)$ reductase subunit alpha ( $\left.\mathrm{mcrA}\right)$ was downregulated at $30^{\circ} \mathrm{C}$ in $\mathrm{Mg}\left(\mathrm{ClO}_{4}\right)_{2}$ and $\mathrm{Na}\left(\mathrm{ClO}_{4}\right)$ enrichments (Fig. 3, Table 1). Although this reduction in expression is consistent with the decreased $\mathrm{CH}_{4}$ production rates observed in these treatments (Fig. 2), the $\mathrm{Ca}\left(\mathrm{ClO}_{4}\right)_{2}$-amended $\mathrm{M}$. barkeri MS, which generated the least $\mathrm{CH}_{4}$, showed no significant difference in expression of the $\mathrm{mcr}$ complex relative to the $30^{\circ} \mathrm{C}$ perchlorate-free control (Fig. 3, Table 1). Furthermore, no elements of $\mathrm{mcr}$ were significantly differentially expressed at $0^{\circ} \mathrm{C}$ in the perchlorate-free control relative to the $30^{\circ} \mathrm{C}$ perchlorate-free control (Fig. 3) despite its far lower $\mathrm{CH}_{4}$ production rate (Fig. 2). Therefore, the 
decreased expression of mcrA does not appear to be sufficient to explain the associated decrease in $\mathrm{CH}_{4}$ production rates with perchlorate exposure at $30^{\circ} \mathrm{C}$ or incubation at $0^{\circ} \mathrm{C}$.

The carbon monoxide dehydrogenase/acetyl-CoA synthase complex (CODH/ACS), which plays a key role in both energy conversation and carbon fixation via the Wood-Ljungdahl pathway, demonstrated significant regulatory changes as a function of perchlorate exposure and temperature. The cooS subunit of $\mathrm{CODH}$, which reversibly converts $\mathrm{CO}$ and $\mathrm{CO}_{2}$, was up-regulated in $30^{\circ} \mathrm{C} \mathrm{Mg}\left(\mathrm{ClO}_{4}\right)_{2}$ and $\mathrm{Na}\left(\mathrm{ClO}_{4}\right)$ treatments (Fig. 3, Table 1). Carbon monoxide dehydrogenase subunit epsilon (cdhe), which recycles ferredoxin in the reversible conversion between $\mathrm{CO}$ and $\mathrm{CO}_{2}$, was up-regulated with $\mathrm{Ca}\left(\mathrm{ClO}_{4}\right)_{2}$ at $30^{\circ} \mathrm{C}(\mathrm{Fig}$. 3, Table 1), but was down-regulated in the $0^{\circ} \mathrm{C} \mathrm{Mg}\left(\mathrm{ClO}_{4}\right)_{2}$ and $\mathrm{Na}\left(\mathrm{ClO}_{4}\right)$ treatments (Fig. 3, Table 2). The $30^{\circ} \mathrm{C} \mathrm{Ca}\left(\mathrm{ClO}_{4}\right)_{2}$ treatment also demonstrated significant up-regulation of $5-\mathrm{H}_{4} \mathrm{SPT}$ :corrinoid Fe-S protein methyltransferase (cdhy), which plays a key role in the generation $\mathrm{H}_{4} \mathrm{SPT}$ and acetyl-CoA for biomass synthesis in the Wood-Ljundal pathway (Fig. 3, Table 1). Both copies of this gene were down-regulated at $0^{\circ} \mathrm{C}$ in the $\mathrm{Mg}\left(\mathrm{ClO}_{4}\right)_{2}$ and $\mathrm{Na}\left(\mathrm{ClO}_{4}\right)$ treatments (Fig. 3, Table 2).

Both alpha and beta chains of ACS, respectively encoded by $c d h$ a and $c d h b$, were down-regulated in the $0^{\circ} \mathrm{C} \mathrm{Na}\left(\mathrm{ClO}_{4}\right)$ treatment with respect to the $0^{\circ} \mathrm{C}$ perchlorate-free control, while only cdha was downregulated in the $0^{\circ} \mathrm{C} \mathrm{Mg}\left(\mathrm{ClO}_{4}\right)_{2}$ treatment (Fig. 3, Table 2). Cdhd, which encodes an iron-sulfur corrinoid protein, was also down-regulated at $0^{\circ} \mathrm{C}$ in $\mathrm{Mg}\left(\mathrm{ClO}_{4}\right)_{2}$ and $\mathrm{Na}\left(\mathrm{ClO}_{4}\right)$-supplemented incubations (Fig. 3, Table 2). We observed no significant differential expression of CODH/ACS complex genes in the $0^{\circ} \mathrm{C}$ $\mathrm{Ca}\left(\mathrm{ClO}_{4}\right)_{2}$ treatment (Fig. 3).

\section{Concurrent up-regulation of ammonium transporters, Mo-nitrogenases, and P-II repressors}

The most substantial up-regulation patterns were observed in genes relating to nitrogen cycling in perchlorate-incubated treatments. The $30^{\circ} \mathrm{C} \mathrm{Mg}\left(\mathrm{ClO}_{4}\right)_{2}$ and $\mathrm{Na}\left(\mathrm{ClO}_{4}\right)$-amended conditions showed positive differential expression of 6 genes in the (Mo)-nitrogenase (hereafter (Mo)-Nase) complex (Fig. 4) including $n i f H$, the MoFe-dinitrogen reductase that is responsible for electron transfer to the $a_{2} b_{2} N_{2}$ binding site (encoded by nifD and nifK, respectively) via ATP hydrolysis, as well as the P-II regulatory repressors, nifl, which shut off $\mathrm{N}_{2}$ fixation when ammonia is bioavailable ${ }^{50-53}$. Biosynthesis and assembly proteins for (Mo)-Nase, nifE and nif $\mathrm{N}$, were also upregulated at $30^{\circ} \mathrm{C}$ with $\mathrm{Mg}\left(\mathrm{ClO}_{4}\right)_{2}$ and $\mathrm{Na}\left(\mathrm{ClO}_{4}\right)$. At $30^{\circ} \mathrm{C}$, only nifH demonstrated significant up-regulation in both the $\left.\mathrm{Ca}(\mathrm{ClO})_{2}\right)_{2}$ and perchloratefree control, but the $0^{\circ} \mathrm{C} \mathrm{Ca}\left(\mathrm{ClO}_{4}\right)_{2}$ treatment also showed significant up-regulation of nifl and nifE (Fig. 4).

We observed substantial up-regulation of ammonium transporters $(a m t)$ in the $30^{\circ} \mathrm{C}$ perchlorate treatments, but no significant differences in amt expression were observed in any $0^{\circ} \mathrm{C}$ treatments (Fig. 4). 
In the $30^{\circ} \mathrm{C} \mathrm{Mg}\left(\mathrm{ClO}_{4}\right)_{2}$ treatment, the complete operon for osmostress protectants uptake $\mathrm{A}$, opuA, observed positive LFC of $0.64 \pm 0.17$ (opuAA, $P<0.001$ ), $0.73 \pm 0.20$ (opuAB, $P<0.001$ ), and $0.66 \pm 0.30$ (opuAC, $P=0.02)$. In the $30^{\circ} \mathrm{C} \mathrm{Na}\left(\mathrm{ClO}_{4}\right)$ treatment, significant up-regulation was also observed for opuAA $\left(\mathrm{LFC}=0.54 \pm 0.17, P=410^{-3}\right)$ and opuAB $\left(\mathrm{LFC}=0.59 \pm 0.20, P=7 \quad 10^{-3}\right)$. OpuA is responsible for the uptake of extracellular glycine betaine, belonging to a family of $A B C$ transporters that hydrolyze ATP to import glycine betaine and other osmoprotectants such as proline $e^{54-56}$. The opu family also includes uptake systems for choline, a glycine betaine precursor ${ }^{56}$, but $M$. barkeri lacks the cellular machinery for de novo glycine betaine synthesis ${ }^{57}$. Relative to the $0^{\circ} \mathrm{C}$ perchlorate-free control, significant downregulation of opuAA in $0^{\circ} \mathrm{C} \mathrm{Mg}\left(\mathrm{ClO}_{4}\right)_{2}\left(\mathrm{LFC}=-0.94 \pm 0.30, P=8.0210^{-3}\right)$ and $\mathrm{Na}\left(\mathrm{ClO}_{4}\right)(\mathrm{LFC}=-0.69 \pm$ $\left.0.31, P=3.1410^{-2}\right)$ treatments was observed. OpuAB was also down-regulated in the $0^{\circ} \mathrm{C} \mathrm{Mg}\left(\mathrm{ClO}_{4}\right)_{2}$ treatment $\left(\mathrm{LFC}=-1.03 \pm 0.38, P=1.5610^{-2}\right)$.

Evidence for osmotic stress can also be observed in the regulation of cell surface protein synthesis. Methanochondroitin is the primary constituent of the extracellular matrix that clumps $M$. barkeri cells into multicellular aggregates under optimal growth conditions ${ }^{58}$. Glucuronic acid, generated from glucose degradation via UDP-glucose dehydrogenase $(U G D H)$, is a major component of methanochondroitin ${ }^{58,59}$. We observed significant down-regulation of $U G D H$ under $\mathrm{Mg}\left(\mathrm{ClO}_{4}\right)_{2}$ and $\mathrm{Na}\left(\mathrm{ClO}_{4}\right)$ conditions at $30^{\circ} \mathrm{C}$ $\left(\mathrm{LFC}_{\mathrm{Mg}}=-0.55 \pm 0.17, P=310^{-3} ; \mathrm{LFC}_{\mathrm{Na}}=-0.51 \pm 0.17, P=7 \quad 10^{-3}\right)$.

\section{Down-regulation of sulfur-containing amino acids}

In addition to the 20 common amino acids, $M$. barkeri also encodes a $21^{\text {st }}$ residue, pyrrolysine, via the 'amber' stop codon $U_{A G}{ }^{60}$. A comparison of the genes encoding amino acid synthesis proteins showed large negative $\log _{2}$-fold changes at $30^{\circ} \mathrm{C}$ in $\mathrm{Mg}\left(\mathrm{ClO}_{4}\right)_{2}$ and $\mathrm{Na}\left(\mathrm{ClO}_{4}\right)$-amended treatments with respect to cysteine-producing proteins cysteine synthase (cysK) and serine acetyltransferase (cysE) (Fig. 5a). Further examination of complete amino acid metabolic pathways (Figs. S4 - S16) revealed that this pattern of substantial gene down-regulation was characteristic of not only cysteine, but also the other sulfur-containing amino acid methionine (Fig. 5b).

\section{Discussion}

In this study we took our inspiration from nearly two decades of research into Martian methane to investigate how methanogens may survive under challenging shallow subsurface conditions of Mars, specifically under freezing temperatures and in the presence of chaotropic perchlorate salts. We tracked $\mathrm{CH}_{4}$ production and changes in global gene expression in $M$. barkeri MS via RNA-Seq following 28 days' incubation at $30^{\circ} \mathrm{C}$ or $0^{\circ} \mathrm{C}$, with and without $10 \mathrm{mM}$ of dissolved $\mathrm{Na}-, \mathrm{Mg}-$, or Ca-perchlorate. In accordance

with prior findings ${ }^{25,26}$ we observed quantifiable but inhibited methanogenesis in cultures under supplemented with perchlorates (Fig. 2). For the first time we present transcriptomic evidence of the 
underlying biochemistry. Regulatory responses point to unambiguous shifts in amino acid synthesis and recycling, as well as mechanisms to combat increased osmotic stress - not unexpected reactions for an obligate anaerobe exposed to strongly oxidizing and chaotropic perchlorate salts. A surprising regulatory switch was observed in the methanogenesis pathway, with a significant up-regulation of methylamineutilizing genes, despite these substrates not being present in the media ab initio. Metalloenzymes with molybdenum active sites, including (Mo)-formylmethanofuran dehydrogenase and (Mo)-Nase were among the most significantly up-regulated genes in perchlorate-amended incubations at $30^{\circ} \mathrm{C}$. We contextualize these revelations with a precedent of perchlorate reduction in methanogenic cultures ${ }^{25,26}$, offering new insight into Mo active sites as hydrogenation catalysts for these reactions to proceed.

\section{Evidence for selection against redox-sensitive amino acids under temperate conditions}

Cysteine and methionine are exceptionally sensitive to oxidation by reactive radical species ${ }^{61}$. Both residues have shown strong binding affinities to both perchlorate and perchloric acid, resulting in the oxidation of methionine to methionine sulfoxide and cysteine to sulfonic acid ${ }^{62}$. The susceptibility of cysteine and methionine to react with perchlorate risks degradation of protein structure and function. The extensive and substantial down-regulation of cysteine and methionine metabolic pathways we observed in the presence of $\mathrm{Na}$ - and $\mathrm{Mg}$-perchlorates at $30^{\circ} \mathrm{C}$ (Fig. 5) suggests a concerted effort by M. barkeri to reduce the synthesis and repair of these residues in the presence of these perchlorate species. A dearth of significant differential expression of amino acid-recycling genes (including those specific for cysteine and methionine) in both $0^{\circ} \mathrm{C}$ and $0^{\circ} \mathrm{C}$ perchlorate treatments demonstrates that freezing conditions are not sufficient to confer a decrease in transcriptional activity. It is clear that the synthesis and processing of essential amino acids in $M$. barkeri must proceed despite the metabolic stresses of frigid temperatures and strong oxidants.

\section{A role for glycine betaine in cryo- and osmoprotection, and as a methylamine precursor}

The regulatory patterns of enzyme complexes protecting against osmotic stress like opuAABC coincide with temperature and redox conditions. This operon is up-regulated at $30^{\circ} \mathrm{C}$ with $\mathrm{Na}\left(\mathrm{ClO}_{4}\right)$ and $\mathrm{Mg}\left(\mathrm{ClO}_{4}\right)_{2}$, implying an increased need for cellular machinery to import glycine betaine to combat osmotic stress. In addition to being an osmoprotectant, glycine betaine is also cryoprotective ${ }^{63}$. While perchlorate salts are highly oxidizing, they also depress the freezing point of water. The down-regulation of opuAB in $\mathrm{Mg}\left(\mathrm{ClO}_{4}\right)_{2}$-amended cultures at $0^{\circ} \mathrm{C}$ might suggest a decreased cold shock response in $M$. barkeri, wherein glycine betaine uptake for its cryoprotective properties was not needed under freezing conditions.

The up-regulation of methylamine-specific methanogenesis pathway genes in all three $30^{\circ} \mathrm{C}$ perchlorate treatments was unexpected. Methylamines were not present in the media $a b$ initio and free energy yields of methylamine methanogenesis reactions at $30^{\circ} \mathrm{C}$ range from -91 to $-143 \mathrm{~kJ} / \mathrm{mol} \mathrm{CH}_{4}$ - significantly less 
than the $-158 \mathrm{~kJ} / \mathrm{mol} \mathrm{CH}_{4}$ of the hydrogenotrophic pathway (Table S3). However, it has been suggested that glycine betaine may be a potential precursor of trimethylamine (TMA) ${ }^{64,65}$. Although an exact mechanism for their formation has not been reported, the observed up-regulation of monomethylamine and dimethylamine permeases $m t m P$ and $m t b P$ (Fig. 3) suggest possible interactions between perchlorates and complex media constituents (e.g., perhaps yeast extract or casitone) that might yield methylamines for utilization by M. barkeri.

\section{Up-regulation of Mo-containing enzymes suggest mechanism for $\mathrm{H}_{2}$-dependent perchlorate reduction.}

Fixed nitrogen was replete under initial incubation conditions $\left(9.3 \mathrm{mM} \mathrm{NH}_{4} \mathrm{Cl}\right.$ plus additional $\mathrm{N}$ from complex ingredients like yeast extract and casitone). The significant up-regulation of ammonium transporters (amt, Fig. 4), methylamine permeases ( $m t m P$ and $m t b P, F i g .3)$, and P-II repressors (nifl, Fig. 4) in $30^{\circ} \mathrm{C}$ perchlorate treatments imply that fixed $\mathrm{N}$ was still available and actively utilized at the time of sample preservation for RNA-Seq. It is therefore surprising to observe a simultaneous and substantial upregulation of nitrogenase genes, an overwhelming proportion of which being associated with the molybdenum isoform, (e.g., nifDEHK, Fig. 4). Nitrogen fixation is an energetically expensive process, consuming at least 16 (and, by one calculation for methanogens ${ }^{66}$, perhaps more than 50 ) moles of ATP per mole of $\mathrm{N}_{2}$ fixed ${ }^{67}$. In M. barkeri, $\mathrm{NH}_{3}$ concentrations as low as $10 \mu \mathrm{M}$ have been shown to be inhibitory to $\mathrm{N}_{2}$ fixation ${ }^{50-53}$. The significant increase in nifl expression in the $30^{\circ} \mathrm{C} \mathrm{Mg}\left(\mathrm{ClO}_{4}\right)_{2}$ and $\mathrm{Na}\left(\mathrm{ClO}_{4}\right)$-amended treatments suggest a concerted effort to dedicate cellular energy towards signaling the shut off of Mo-Nase activity. What is the purpose of this transcriptional arms race?

Microbial perchlorate reduction has been identified throughout the Proteobacteria ${ }^{68-70}$, as well as halophilic ${ }^{71}$ and hyperthermophilic Archaea ${ }^{72}$. The substrate-specific and Mo-containing perchlorate reductase ( $p c r A B)$, which reduces perchlorate to chlorite $\left(\mathrm{ClO}_{2}^{-}\right)$, and chlorite dismutase $(c / d)$, which dismutates $\mathrm{ClO}_{2}{ }^{-}$into chloride $\left(\mathrm{Cl}^{-}\right)$and molecular oxygen $\left(\mathrm{O}_{2}\right)$, have been isolated and purified ${ }^{68}$. However, chlorate- and perchlorate-binding affinities have been documented in structurally similar a- and b-subunits of other Mo-containing DMSO family reductases ${ }^{68,73,74}$. A plethora of inorganic and organic electron donors have also been implicated in microbial perchlorate reduction ${ }^{68,75-77}$ including $\mathrm{H}_{2}$, sulphide $\left(\mathrm{S}_{2}{ }^{-}\right), \mathrm{CH}_{4}$, and yeast extract, which are available constituents in the incubations analyzed in this study. The biochemistry of microbial perchlorate reduction is complex and not yet fully understood. Nonetheless, the following environmental conditions must be met in order for perchlorate reduction to proceed: 1) dissolved $\mathrm{O}_{2}$ concentrations must be $<2 \mathrm{mg} \mathrm{L}^{-1}$; 2) $\mathrm{NO}_{3}^{-}$must be completely consumed; and 3) molybdenum must be bioavailable as molybdate, $\mathrm{MoO}_{4}{ }^{2-}$, to synthesize Mo cofactors ${ }^{68,78}$ in perchlorate-reducing metalloenzymes. All three conditions were coincidentally satisfied in this study's incubation conditions. 
Perchlorate reduction has been observed in sterile methanogenic media under an $80: 20 \mathrm{H}_{2}: \mathrm{CO}_{2}$ atmosphere ${ }^{25,26}$ and apparently exacerbated in media with the psychrotolerant methanogen Methanobacterium arcticum $\mathrm{M} 2$, leading to the suggestion that perchlorate could be utilized as a possible electron acceptor in a reversal of methanogenesis - the anaerobic oxidation of methane, $\mathrm{AOM}^{25}$ (Equation 1). To date these interpretations remain unverified. In this study, we similarly observed a significant decrease in perchlorate concentrations in media containing M. barkeri - a loss of $17.4 \%$ for $\mathrm{Mg}\left(\mathrm{ClO}_{4}\right)_{2}, 26.8 \%$ for $\mathrm{Ca}\left(\mathrm{ClO}_{4}\right)_{2}$, and $58.9 \%$ of $\mathrm{Na}\left(\mathrm{ClO}_{4}\right)$ by mass. Anion measurements in these samples did yield an increase in total $\mathrm{Cl}^{-}$in perchlorate-amended incubations, but only enough to account for $35.5 \% \mathrm{Mg}\left(\mathrm{ClO}_{4}\right)_{2}, 5.6 \% \mathrm{Ca}\left(\mathrm{ClO}_{4}\right)_{2}$, and $44.8 \%$ of $\mathrm{Na}\left(\mathrm{ClO}_{4}\right)$ apparently reduced (preliminary data, unpublished). Additional resources and measurements in a future study are necessary to quantify other reduced intermediates (e.g. $\mathrm{ClO}_{3}{ }^{-}$and $\mathrm{ClO}_{2}{ }^{-}$) to fully assess the fate of $\mathrm{ClO}_{4}{ }^{-}$.

\section{$\mathrm{CH}_{4}+\mathrm{ClO}_{4}^{-} \leftrightarrow \mathrm{CO}_{2}+\mathrm{Cl}^{-}+2 \mathrm{H}_{2} \mathrm{O}$}

Sodium sulphide, $\mathrm{Na}_{2} \mathrm{~S}$, a common reducing agent in anaerobic media, has been previously ruled out as a significant contributor to abiotic perchlorate reduction in methanogenic media (medium MSH in Kral et al.) ${ }^{26}$. Yeast extract is a complex and undefined carbon source, and its inclusion in sterile MSH media has been associated with increased rates of perchlorate reduction compared to a minimal salts medium (medium MM in Kral et al. ${ }^{26}$. In this study, preliminary measurements of perchlorate concentrations in sterile 120a media yielded inconclusive evidence of perchlorate reducation (data not shown). More work is necessary to fully explore the composition and role of yeast extract as a potential reducing agent.

The free energy yield of $\mathrm{H}_{2}$ oxidation coupled to perchlorate reduction (Equation 2) is substantial $\left(\Delta \mathrm{G}^{0^{\prime}}=\right.$ $-289 \mathrm{~kJ} / \mathrm{mol} \mathrm{H}_{2}$ ) but the reaction is kinetically sluggish at ambient conditions and requires a metallic catalyst to overcome its large activation energy ${ }^{79}$.

$$
4 \mathrm{H}_{2}+\mathrm{ClO}_{4}^{-} \leftrightarrow \mathrm{Cl}^{-}+4 \mathrm{H}_{2} \mathrm{O}
$$

Nickel (Ni) has long been known as an excellent hydrogenation catalyst ${ }^{80}$ and is an essential cofactor for hydrogenase activity in methanogens ${ }^{81}$, but an essential role in microbial perchlorate reduction has never been suggested and it is not obvious from our transcriptomic data that perchlorates elicit a universal response by $\mathrm{Ni}$ active sites in hydrogenases (e.g. echE, vhtA, and frha in Fig. 3). Instead, given perchlorate reduction's known Mo dependency ${ }^{68,82}$ and the additional empirical evidence presented here, we cannot ignore the most parsimonious explanation: the substantial up-regulation of (Mo)-Nase (Fig. 4) and (Mo)formylmethanofuran dehydrogenase (Fig. 3 , Table 1 ) at $30^{\circ} \mathrm{C}$ must be associated with perchlorate reduction. Certainly, a thorough investigation is warranted in order to elucidate finer details of the biochemistry. 


\section{Methylamine methanogenesis as a mechanism for energy conservation}

In methylamine methanogenesis, $\mathrm{H}_{2}$ is recycled by the partial reversal of the methanogenesis pathway, generated via the oxidation of $\mathrm{F}_{420} \mathrm{H}_{2}$ by frha and the oxidation of ferredoxin by echF (green arrows in Figs. 3). $\mathrm{H}_{2}$ generated by the oxidation of $\mathrm{F}_{420} \mathrm{H}_{2}$ and ferredoxin diffuses across the membrane to be oxidized by $v h t \mathrm{~A}$ in an energy conserving scheme to recycle methanophenazine (MP) ${ }^{83-86}$. Ferredoxin oxidation by ech $\mathrm{F}$ also results in the translocation of $2 \mathrm{H}^{+}$through ech, contributing to the production of a proton gradient (high outside the cell) ${ }^{86}$. Evidence for the generation of this proton gradient might be indicated in our incubations based on drops in $\mathrm{pH}$ (up to $0.77 \mathrm{pH}$ units) (Table S4). Based on upregulation of the genes for methylamine methanogenesis, we attribute the differential expression of ech, $v h t$, and frh hydrogenases (Fig. 3) and ferredoxin (Tables S9, S11, S13) as putative sources of a proton motive force in the $30^{\circ} \mathrm{C} \mathrm{Ca}\left(\mathrm{ClO}_{4}\right)_{2}$-supplemented incubations.

We theorize that the thermodynamic spontaneity of $\mathrm{H}_{2}$-dependent perchlorate reduction (in the presence of a Mo catalyst) results in it outcompeting the endergonic first step of hydrogenotrophic methanogenesis (Equation 3; $\left.\Delta \mathrm{G}^{\mathrm{o}^{\prime}}=+16 \mathrm{~kJ} / \mathrm{mol} \mathrm{H}_{2}\right)^{87}$ (Fig. 6a).

Likewise, we imagine $\mathrm{H}_{2}$ intermediates generated during energy conserving steps of methylamine methanogenesis are siphoned off to reduce perchlorate in lieu of reducing MP via vht $\left(\Delta \mathrm{G}^{0^{\prime}}=-289 \mathrm{~kJ} / \mathrm{mol}\right.$ $\mathrm{H}_{2}$ for perchlorate reduction ${ }^{88}$ vs. $\Delta \mathrm{G}^{\mathrm{o}^{\prime}}=-50 \mathrm{~kJ} / \mathrm{mol} \mathrm{H}_{2}$ for MP reduction ${ }^{89,90}$ ) (Fig. 6b). Such interpretations warrant further investigation, but do fit within previously reported narratives of observed decreases in $\mathrm{CH}_{4}$ production in perchlorate-supplemented methanogenic cultures ${ }^{25,26}$.

$$
\mathrm{CO}_{2}+{ }^{\dagger} \mathrm{MFR}-\mathrm{NH}_{3}{ }^{+}+\mathrm{H}_{2} \leftrightarrow{ }^{\dagger \dagger} \mathrm{CHO}-\mathrm{NH}-\mathrm{MFR}+\mathrm{H}_{2} \mathrm{O}+\mathrm{H}^{+}
$$

\section{†'Methanofuran \\ ††Formyl-methanofuran}

\section{Do all perchlorates trigger universal regulatory responses?}

Calcium-, magnesium- and sodium perchlorate were investigated in this study as they have been detected in active Recurring Slope Lineae (RSL) on Mars ${ }^{40}$. Until now, studies investigating methanogen survival in high concentrations of perchlorate salts have been unable to ascertain the specific metabolic responses behind observed decreases in $\mathrm{CH}_{4}$ production, and whether these metabolic responses are universal regardless of the perchlorate's constituent cation. Our work demonstrates that, for $M$. barkeri MS transcriptomes assembled after 28 days of incubation, methanogenesis regulatory patterns are consistent across all three perchlorate conditions with methylamine utilization and a handful of (Mo)-fmd subunits at $30^{\circ} \mathrm{C}$ (Figure 3). Otherwise, global expression patterns in $\mathrm{Ca}\left(\mathrm{ClO}_{4}\right)_{2}$ treatments were somewhat distinct from $\mathrm{Na}\left(\mathrm{ClO}_{4}\right)$ and $\mathrm{Mg}\left(\mathrm{ClO}_{4}\right)_{2}$ conditions, which, on the whole, exhibited similar transcriptomic responses at both temperatures (Figs. 4-5; Tables 1-2). Transcriptomes from additional 
time points can help clarify whether these discrepancies in expression are reflective of distinct metabolic responses to Ca-perchlorate versus $\mathrm{Mg}$ - and $\mathrm{Na}$-perchlorate, or simply different stages of metabolism following prolonged exposure to perchlorates in general. We infer the latter is more likely given the novel and ubiquitous response of genes in the methylamine methanogenesis pathway.

\section{Implications for Martian methane}

These findings better constrain our growing understanding of how microbial life responds to strong oxidants, freezing temperatures, osmotic stress, and nutrient limitation - i.e., conditions characteristic of any habitable Martian environment where we may hope to find extant life. Notably, our study shows that major metabolic disruption by perchlorates at $30^{\circ} \mathrm{C}$ is not reflected to the same degree at $0^{\circ} \mathrm{C}$, which is more appropriately representative of the conditions at Mars Special Regions ${ }^{91}$. This finding offers new perspectives to contextualize observations of Martian $\mathrm{CH}_{4}$, particularly in situ measurements made by the Curiosity rover ${ }^{5,6}$, as diffuse emissions of trace $\mathrm{CH}_{4}$ are not inconsistent with our observations of decreased methanogenesis under freezing temperatures. This work offers a glimpse into the remarkable adaptability of methanogens to survive under oxidative stresses that mimic the Martian subsurface. The inferences made from this study provide many exciting opportunities for further research to better understand methanogen ecophysiology in the context of a potential role in the Martian methane story.

\section{Materials And Methods}

Materials and culture conditions. Methanosarcina barkeri wild-type strain MS (ATCC ${ }^{\circledR} 515820$ ) was grown hydrogenotrophically ( $15 \mathrm{~mL}$ of $80: 20 \mathrm{H}_{2}: \mathrm{CO}_{2}$ headspace pressurized to $1.5 \mathrm{bar}$ ) in anaerobic balch tubes (Chemglass Life Sciences LLC, Vineland, NJ USA) containing $9 \mathrm{~mL}$ DSMZ medium 120a, 10 $\mathrm{mg} / \mathrm{L}$ EDTA ( $\mathrm{pH} 7.0$ to 7.2$)^{92}$, supplemented with trace element solution SL-1093 and vitamin supplement MD-VS (ATCC ${ }^{\circledR}$, Manassas, VA USA). Media assaying for perchlorate tolerance were augmented to $10 \mathrm{mM}$ (final concentration) $\mathrm{NaClO}_{4}, \mathrm{Mg}\left(\mathrm{ClO}_{4}\right)_{2}$, or $\mathrm{Ca}\left(\mathrm{ClO}_{4}\right)_{2}$. Balch tubes were inoculated with $1 \mathrm{~mL}$ cell suspensions containing $\sim 4 \times 10^{7}$ cells and incubated in batches of 9 biological replicates plus one autoclave-sterilized media blank for 28 days (Fig. S17). For each experimental treatment (perchlorate-free control, $\mathrm{NaClO}_{4}, \mathrm{Mg}\left(\mathrm{ClO}_{4}\right)_{2}$, or $\left.\mathrm{Ca}\left(\mathrm{ClO}_{4}\right)_{2}\right)$, optical density measurements (OD) and $\mathrm{CH}_{4}$ production were monitored weekly in parallel experiments incubated at $30^{\circ} \mathrm{C}$ or $0^{\circ} \mathrm{C}$ (Fig. 2).

OD measurements were performed spectrophotometrically at $600 \mathrm{~nm}$ using a Genesys 30 Visible Spectrometer (Thermo-Scientific Corp., Madison, WI USA). At the end of the incubation experiment, direct cell counts were performed on enrichment aliquots fluorescently stained with Acridine Orange (AO) dye (catalogue \#318337, Sigma-Aldrich Chemical, Co., Milwaukee, WI USA) (50 $\mu \mathrm{M}$ final concentration) following an established procedure ${ }^{94}$. Stained cells were enumerated in a Spotlite hemocytometer counting chamber (McGaw Park, IL USA) with a Zeiss Axioskope 40 epifluorescence microscope (ZEISS 
Microscopy, Jena, Germany) at 600' magnification using an AO filter cube set (excitation 470/20 nm; emission $>510 \mathrm{~nm}$ ).

Headspace gas samples were collected via gas-tight syringes (catalogue \#24886, Restek U.S., Bellefonte, PA USA) to measure $\mathrm{CO}_{2} \mathrm{CH}_{4}$ using a Trace 1310 gas chromatograph equipped with a flame-ionizing detector (GC-FID) (ThermoFisher Scientific, Waltham, MA USA). $\mathrm{H}_{2}$ was measured using a Peak Performer 1 series gas chromatograph coupled to a thermal conductivity detector (GC-TCD; Peak Laboratories, Mountain View, CA USA). To avoid injecting atmospheric $\mathrm{O}_{2}$ and residual carrier-over of trace gases within the syringes between samples, all syringes were flushed three times with ultra-high purity nitrogen gas $\left(\mathrm{UHP} \mathrm{N}_{2}\right.$ ) between samples.

Single experimental replicates from each condition were reserved for perchlorate and other anion measurements. Media was diluted $500^{\prime}$ in milliQ $\mathrm{H}_{2} \mathrm{O}$ and compositional analysis was performed on a Dionex ${ }^{\mathrm{TM}}$ ICS-5000+ Capillary HPIC ${ }^{\mathrm{TM}}$ system coupled to an MSQ-quadruple mass spectrometer (ThermoFisher Scientific, Waltham, MA USA). Perchlorates were separated from other anions using a Dionex $^{\mathrm{TM}}$ IonPac $^{\mathrm{TM}}$ AS16 guard column set (ThermoFisher Scientific, Waltham, MA USA). TraceCERT ${ }^{\circledR}$ perchlorate standard (catalogue \#76462, Sigma-Aldrich Chemical, Co., Milwaukee, WI USA) and Dionex ${ }^{\text {TM }}$ Combined Seven Anion II (catalogue \# 057590, ThermoFisher Scientific, Waltham, MA USA) were used to generate referential standard curves.

RNA isolation and purification. After 28 days' incubation, culture and blank volume contents were briefly vortexed and aseptically transferred into sterile $15 \mathrm{~mL}$ Falcon ${ }^{\circledR}$ tubes (Corning Inc., Corning, NY USA) at incubation temperature inside a Coy anaerobic chamber (Coy Laboratory Products Inc., Grass Lake, MI USA). Tubes were centrifuged at 3,000 ' $\mathrm{g}$ for 1 minute using an IEC Centra CL2 centrifuge (Thermo Electron Company, Milford, MA USA) to pellet cells. Media was poured off for $\mathrm{pH}$ and electrical conductivity measurements, leaving behind $1 \mathrm{~mL}$. To ensure quantifiable RNA yields downstream, the nine biological replicates from each condition were consolidated into three sets of three samples each for extraction ( $3 \mathrm{~mL}$ pelleted cell suspension/tube). RNAlater solution (ThermoFisher Scientific, Waltham, MA USA) was added to a final volume of $\sim 12 \mathrm{~mL}$. Samples were left to equilibrate at incubation temperature for 3 hours, transferred to $4^{\circ} \mathrm{C}$ for 24 hours, and then stored at $-80^{\circ} \mathrm{C}$ until overnight shipment on dry ice to Princeton University for RNA extraction.

Samples preserved at $-80^{\circ} \mathrm{C}$ in RNAlater were thawed on ice in a sealed container before contents were transferred to $50 \mathrm{~mL}$ Falcon ${ }^{\circledR}$ tubes. An equal volume $(12 \mathrm{~mL}$ ) of nuclease-free water (Qiagen, Hilden, Germany) was added to RNAlater-preserved samples, briefly vortexed, and centrifuged at 5,000 $\mathrm{g}$ for 10 minutes using a Sorvall Legend XI centrifuge (ThermoFisher Scientific, Waltham, MA USA). The supernatant was subsequently discarded, and RNA was extracted following a modified protocol from a Zymo Quick-RNA Miniprep Plus Kit (Zymo Research, Irvine, CA USA). RNA lysis buffer and nuclease-free water were added to each sample in a 5:1 ratio, and sterile $0.7 \mathrm{~mm}$ garnet bashing beads (Qiagen, Hilden, 
Germany) were added to facilitate mechanical lysis during subsequent vortexing. Samples were then vortexed for 1 minute and centrifuged at $10,000 \mathrm{~g}$ at $4^{\circ} \mathrm{C}$ for 1 minute using an Eppendorf $5810 \mathrm{R}$ (Eppendorf, Hamburg, Germany) to pellet cell debris. The supernatant containing total nucleic acids was transferred to a yellow Spin-Away ${ }^{\mathrm{TM}}$ column (Zymo Research, Irvine, CA USA) fitted in a $2 \mathrm{ml}$ collection tube. Samples were centrifuged at 10,000 g for 1 minute using an AccuSpin Micro 17 (ThermoFisher Scientific, Waltham, MA USA) to separate out genomic DNA. Following centrifugation, the Spin-Away ${ }^{\text {TM }}$ filter was discarded and the filtrate was collected from the column for RNA purification.

Total nucleic acids were then precipitated by adding $1 \mathrm{~mL}$ of chilled absolute ethanol. Pellets were mixed by pipetting and then transferred to green Zymo-Spin ${ }^{T M}$ IIICG column filters fitted in clean collection tubes. Samples were centrifuged at 10,000 g for 30 seconds to collect precipitated nucleic acids on the column, subsequently treated with $400 \mu \mathrm{L}$ RNA wash buffer, and centrifuged for 30 seconds at $10,000 \mathrm{~g}$. The wash buffer was discarded and columns were treated with $80 \mu \mathrm{L}$ DNAse I reaction mixture (per $80 \mu \mathrm{L}: 5$ $\mu \mathrm{L}$ DNAse 1 [1 U/ $\mu \mathrm{L}$ ], $8 \mu \mathrm{L}$ 10X DNAse I reaction buffer [Zymo Research, Irvine, CA USA], $3 \mu \mathrm{L}$ nucleasefree water, $64 \mu \mathrm{L}$ RNA wash buffer [Zymo Research, Irvine, CA USA]) to degrade trace genomic DNA and left to incubate on ice in the dark for 15 minutes. DNAse-treated samples were then centrifuged at 10,000 $\mathrm{g}$ for 30 seconds. The reaction buffers were discarded, column filters were washed three times with 400 , 700, and $400 \mu \mathrm{l}$ of RNA Prep Buffer (Zymo Research, Irvine, CA USA), centrifuging twice for 30 seconds at $10,000 \mathrm{~g}$ and at $16,000 \mathrm{~g}$ for 2 minutes for the final wash. Total RNA was then eluted into sterile, nuclease-free PCR tubes on ice using nuclease-free water pre-heated to $95^{\circ} \mathrm{C}$. Total RNA was quantified using a Qubit hs RNA assay kit coupled to a Qubit 2.0 analyzer (ThermoFisher Scientific, Waltham, MA USA) following the manufacturer's protocol. RNA quality was subsequently assessed using a 2100 Bioanalyzer (Agilent Technologies Inc., Santa Clara, CA USA). RNA samples were kept at $-20^{\circ} \mathrm{C}$ until library preparation and sequencing.

All RNA extraction steps were performed using nuclease-free pipette tips (Corning Inc., Corning, NY USA) in a UV-sterilized laminar flow hood. All surfaces, pipettes, and gloves were wiped down at each step with RNaseZap ${ }^{\circledR}$ solution (ThermoFisher Scientific, Waltham, MA USA) to minimize potential RNase contamination. Parallel extraction blanks of extraction kit reagents and blank growth media co-incubated with $M$. barkeri enrichment cultures were performed to ensure cleanliness of the extraction procedure and sterility of uninoculated growth media.

RNA library prep and RNA-Seq. Ribosomal RNA was depleted from total RNA using a Ribo-Zero Bacterial rRNA Removal Kit (Illumina, Inc., San Diego, CA USA) following the manufacturer's instructions and using the provided universal probe sequence. One-directional library prep was performed for each treatment and its constituent 3 sequencing replicates using the Nextera DNA Flex Library Prep Kit (Illumina, Inc., San Diego, CA USA) on the automated Apollo ${ }^{0} 324$ system (Takara Bio USA, Inc., Mountain View, CA, USA). RNA-Seq was carried out for 318 cycles on two lanes of a NovaSeq SP Flowcell (Illumina, Inc., San Diego, CA USA) (1 x $150 \mathrm{bp})$ at the Princeton University genomics core facility.

Page $13 / 28$ 
Annotation and comparative transcriptomics. Quality filtering of single-end reads was performed using fastp v. $0.12 .6^{95}$, removing reads $<50 \mathrm{nt}$, containing $>1 \mathrm{Ns}$, Phred quality scores $<30$, and sample barcode sequences. Using Bowtie2 v.2.3.2 ${ }^{96}$, retained, quality-filtered reads from each experiment were mapped to coding sequence (CDS) regions subset from the complete $M$. barkeri MS reference genome obtained from NCBI GenBank (NZ_CP009528.1). CDS-mapped reads were then sorted, indexed, and processed for extraction from the sequenced transcriptome using Samtools v.1.5 $5^{97}$ and BEDTools v.2.17.0 ${ }^{98}$. Gene annotation was performed using NCBI BLASTn v.2.2.29+ ${ }^{99}$ against a reference $M$. barkeri MS CDS assembly database generated using option -makeblastdb. Protein assignment was determined as the entry with the greatest sequence identity alignment with the query sequence, the lowest E-value, and largest bit score. Differential expression analysis of investigated treatments relative to the $30^{\circ} \mathrm{C}$ and $0^{\circ} \mathrm{C}$ perchlorate-free controls, within-group (i.e. biological replicate) variance estimation, and FPM were performed using DESeq2 ${ }^{100}$. Metabolic pathway involvement of identified genes was determined by referencing the Kyoto Encyclopedia of Genes and Genomes (KEGG) ${ }^{101}$.

\section{Declarations}

\section{DATA AVAILABILITY}

RNA-Seq data is available at NCBI GenBank under accession number PRJNA635445 (Sequence Read Archive SRP265010). The source code of all transcriptomic analyses presented in this manuscript are available upon request.

\section{ACKNOWLEDGEMENTS}

This research was supported by NASA Exobiology Grant NNX17AK87G to ACS, TCO, and RLH. RLH was also supported by National Science Foundation grant DGE-1148900. YT was funded by the Princeton Environmental Institute as part of the 2019 PEl summer internship program. The authors thank Dr. Xinning Zhang, Katja Luxem, and Dr. Peter Girguis for sharing thoughtful insights which helped inform interpretations made in this manuscript.

\section{AUTHOR CONTRIBUTIONS}

$\mathrm{RLH}, \mathrm{ACS}$, and TCO conceived of the study. ACS performed growth experiments on M. barkeri and preserved cultures for RNA isolation, which was performed by RLH and YT. ACS and ZKG performed gas headspace measurements and ZKG performed ion chromatography. WW designed the RNA-Seq experiment and RNA sequencing was performed at the Princeton University Genomics Core Facility. RLH 
performed transcriptomic analyses and consulted with TCO to inform the discussion. All authors contributed to the writing of this manuscript.

\section{DISCLOSURE STATEMENT}

The authors declare no conflicts of interest.

\section{References}

1. Krasnopolsky, V. A., Maillard, J. P. \& Owen, T. C. Detection of methane in the martian atmosphere: evidence for life? Icarus 172, 537-547 (2004).

2. Formisano, V., Atreya, S., Encrenaz, T., Ignatiev, N. \& Giuranna, M. Detection of Methane in the Atmosphere of Mars. Science 306, 1758-1761 (2004).

3. Geminale, A., Formisano, V. \& Giuranna, M. Methane in Martian atmosphere: Average spatial, diurnal, and seasonal behaviour. Planet. Space Sci. 56, 1194-1203 (2008).

4. Mumma, M. J. et al. Strong Release of Methane on Mars in Northern Summer 2003. Science 323, 1041-1045 (2009).

5. Webster, C. R. et al. Mars methane detection and variability at Gale crater. Science $\mathbf{3 4 7}, \mathbf{4 1 5 - 4 1 7}$ (2015).

6. Webster, C. R. et al. Background levels of methane in Mars' atmosphere show strong seasonal variations. Science. 360, 1093-1096 (2018).

7. Korablev, O. et al. No detection of methane on Mars from early ExoMars Trace Gas Orbiter observations. Nature 568, 517-520 (2019).

8. Fries, M. et al. A cometary origin for martian atmospheric methane. Geochemical Perspect. Lett. 2, 10-23 (2016).

9. Keppler, F. et al. Ultraviolet-radiation-induced methane emissions from meteorites and the Martian atmosphere. Nature 486, 93-96 (2012).

10. Moores, J. E. \& Schuerger, A. C. UV degradation of accreted organics on Mars: IDP longevity, surface reservoir of organics, and relevance to the detection of methane in the atmosphere. J. Geophys. Res. Planets 117, E8 (2012).

11. Schuerger, A. C., Moores, J. E., Clausen, C. A., Barlow, N. G. \& Britt, D. T. Methane from UV-irradiated carbonaceous chondrites under simulated Martian conditions. J. Geophys. Res. Planets 117, E8 (2012).

12. Etiope, G., Ehlmann, B. L. \& Schoell, M. Low temperature production and exhalation of methane from serpentinized rocks on Earth: A potential analog for methane production on Mars. Icarus 224, 276285 (2013). 
13. Oehler, D. Z. \& Etiope, G. Methane Seepage on Mars: Where to Look and Why. Astrobiology 17, 12331264 (2017).

14. Onstott, T. C. et al. Martian CH 4: Sources, Flux, and Detection. Astrobiology 6, 377-395 (2006).

15. Elwood Madden, M. E., Ulrich, S. M., Onstott, T. C. \& Phelps, T. J. Salinity-induced hydrate dissociation: A mechanism for recent $\mathrm{CH} 4$ release on Mars. Geophys. Res. Lett. (2007) doi:10.1029/2006GL029156.

16. Conrad, R. The global methane cycle: recent advances in understanding the microbial processes involved. Environ. Microbiol. Rep. 1, 285-292 (2009).

17. Kendrick, M. G. \& Kral, T. A. Survival of Methanogens During Desiccation: Implications for Life on Mars. Astrobiology 6, 546-551 (2006).

18. Anderson, K. L., Apolinario, E. E. \& Sowers, K. R. Desiccation as a long-term survival mechanism for the archaeon Methanosarcina barkeri. Appl. Environ. Microbiol. 78, 1473-1479 (2012).

19. Kral, T. A. \& Altheide, S. T. Methanogen survival following exposure to desiccation, low pressure and martian regolith analogs. Planet. Space Sci. 89, 167-171 (2013).

20. Sowers, K. R. \& Gunsalus, R. P. Adaptation for growth at various saline concentrations by the archaebacterium Methanosarcina thermophila. J. Bacteriol. 170, 998-1002 (1988).

21. Maestrojuan, G. M. et al. Taxonomy and Halotolerance of Mesophilic Methanosarcina Strains, Assignment of Strains to Species, and Synonymy of Methanosarcina mazei and Methanosarcina frisia. Int. J. Syst. Bacteriol. 42, 561-567 (1992).

22. Sowers, K. R., Boone, J. E. \& Gunsalus, R. P. Disaggregation of Methanosarcina spp. and Growth as Single Cells at Elevated Osmolarity. Appl. Environ. Microbiol. 59, 3832-9 (1993).

23. Sowers, K. R. \& Gunsalus, R. P. Halotolerance in Methanosarcina spp.: Role of N(sup(epsilon))-Acetyl(beta)-Lysine, (alpha)-Glutamate, Glycine Betaine, and K(sup+) as Compatible Solutes for Osmotic Adaptation. Appl. Environ. Microbiol. 61, 4382-4388 (1995).

24. Roessler, M. et al. Identification of a Salt-Induced Primary Transporter for Glycine Betaine in the Methanogen Methanosarcina mazei Go1. Appl. Environ. Microbiol. 68, 2133-2139 (2002).

25. Shcherbakova, V., Oshurkova, V. \& Yoshimura, Y. The Effects of Perchlorates on the Permafrost Methanogens: Implication for Autotrophic Life on Mars. Microorganisms 3, 518-534 (2015).

26. Kral, T. A. et al. Sensitivity and adaptability of methanogens to perchlorates: Implications for life on Mars. Planet. Space Sci. 120, 87-95 (2016).

27. Rivkina, E. M., Laurinavichus, K. S., Gilichinsky, D. A. \& Shcherbakova, V. A. Methane generation in permafrost sediments. Dokl. Biol. Sci. 179-181 (2002) doi:10.1023/A:1015366613580.

28. Rivkina, E. et al. Microbial life in permafrost. Adv. Sp. Res. 33, 1215-1221 (2004).

29. Rivkina, E. et al. Biogeochemistry of methane and methanogenic archaea in permafrost. FEMS Microbiol. Ecol. 61, 1-15 (2007).

30. Takai, K. et al. Cell proliferation at 122 degrees $\mathrm{C}$ and isotopically heavy $\mathrm{CH} 4$ production by a hyperthermophilic methanogen under high-pressure cultivation. Proc. Natl. Acad. Sci. U. S. A. 105, 
10949-10954 (2008).

31. Sinha, N., Nepal, S., Kral, T. \& Kumar, P. Survivability and growth kinetics of methanogenic archaea at various pHs and pressures: Implications for deep subsurface life on Mars. Planet. Space Sci. 136, 15-24 (2017).

32. Chastain, B. K. \& Kral, T. A. Approaching Mars-like Geochemical Conditions in the Laboratory: Omission of Artificial Buffers and Reductants in a Study of Biogenic Methane Production on a Smectite Clay. Astrobiology 10, 889-897 (2010).

33. Kral, T. A., Altheide, T. S., Lueders, A. E. \& Schuerger, A. C. Low pressure and desiccation effects on methanogens: Implications for life on Mars. Planet. Space Sci. 59, 264-270 (2011).

34. Mickol, R. L. \& Kral, T. A. Low Pressure Tolerance by Methanogens in an Aqueous Environment: Implications for Subsurface Life on Mars. Orig. Life Evol. Biosph. 47, 511-532 (2017).

35. Hecht, M. H. et al. Detection of Perchlorate and the Soluble Chemistry of Martian Soil at the Phoenix Lander Site. Science 325, 64-67 (2009).

36. Navarro-González, R., Vargas, E., de la Rosa, J., Raga, A. C. \& McKay, C. P. Reanalysis of the Viking results suggests perchlorate and organics at midlatitudes on Mars. J. Geophys. Res. 115, E12010 (2010).

37. Glavin, D. P. et al. Evidence for perchlorates and the origin of chlorinated hydrocarbons detected by SAM at the Rocknest aeolian deposit in Gale Crater. J. Geophys. Res. Planets 118, 1955-1973 (2013).

38. Kounaves, S. P. et al. Identification of the perchlorate parent salts at the Phoenix Mars landing site and possible implications. Icarus 232, 226-231 (2014).

39. Kounaves, S. P., Carrier, B. L., O’Neil, G. D., Stroble, S. T. \& Claire, M. W. Evidence of martian perchlorate, chlorate, and nitrate in Mars meteorite EETA79001: Implications for oxidants and organics. Icarus 229, 206-213 (2014).

40. Ojha, L. et al. Spectral evidence for hydrated salts in recurring slope lineae on Mars. Nat. Geosci. (2015) doi:10.1038/ngeo2546.

41. Clark, B. C. \& Kounaves, S. P. Evidence for the distribution of perchlorates on Mars. Int. J. Astrobiol. 15, 311-318 (2016).

42. Pestova, O. N., Myund, L. A., Khripun, M. K. \& Prigaro, A. V. Polythermal Study of the Systems $\mathrm{M}(\mathrm{ClO} 4) 2-\mathrm{H} 2 \mathrm{O}$ (M2+ = Mg2+, Ca2+, Sr2+, Ba2+). Russ. J. Appl. Chem. 78, 409-413 (2005).

43. Chevrier, V. F., Hanley, J. \& Altheide, T. S. Stability of perchlorate hydrates and their liquid solutions at the Phoenix landing site, Mars. Geophys. Res. Lett. 36, L10202 (2009).

44. Marion, G. M., Catling, D. C., Zahnle, K. J. \& Claire, M. W. Modeling aqueous perchlorate chemistries with applications to Mars. Icarus 207, 675-685 (2010).

45. Stillman, D. E. \& Grimm, R. E. Dielectric signatures of adsorbed and salty liquid water at the Phoenix landing site, Mars. J. Geophys. Res. 116, E09005 (2011). 
46. Toner, J. D., Catling, D. C. \& Light, B. The formation of supercooled brines, viscous liquids, and lowtemperature perchlorate glasses in aqueous solutions relevant to Mars. Icarus 233, 36-47 (2014).

47. Nikolakakos, G. \& Whiteway, J. A. Laboratory investigation of perchlorate deliquescence at the surface of Mars with a Raman scattering lidar. Geophys. Res. Lett. 42, 7899-7906 (2015).

48. Maeder, D. L. et al. The Methanosarcina barkeri Genome: Comparative Analysis with Methanosarcina acetivorans and Methanosarcina mazei Reveals Extensive Rearrangement within Methanosarcinal Genomes. J. Bacteriol. 188, 7922-7931 (2006).

49. Sorek, R. \& Cossart, P. Prokaryotic transcriptomics: a new view on regulation, physiology and pathogenicity. Nat. Rev. Genet. 11, 9-16 (2010).

50. Lobo, A. L. \& Zinder, S. H. Diazotrophy and Nitrogenase Activity in the Archaebacterium Methanosarcina barkeri 227. Appl. Environ. Microbiol. 54, 1656-61 (1988).

51. Lobo, A. L. \& Zinder, S. H. Nitrogenase in the archaebacterium Methanosarcina barkeri 227. J. Bacteriol. 172, 6789-6796 (1990).

52. Kessler, P. S. \& Leigh, J. A. Genetics of nitrogen regulation in Methanococcus maripaludis. Genetics 152, 1343-51 (1999).

53. Kessler, P. S., Daniel, C. \& Leigh, J. A. Ammonia Switch-Off of Nitrogen Fixation in the Methanogenic Archaeon Methanococcus maripaludis: Mechanistic Features and Requirement for the Novel GInB Homologues, Nifl1 and Nifl2. J. Bacteriol. 183, 882-889 (2001).

54. Kempf, B. \& Bremer, E. OpuA, an Osmotically Regulated Binding Protein-dependent Transport System for the Osmoprotectant Glycine Betaine in Bacillus subtilis. J. Biol. Chem. 270, 16701-16713 (1995).

55. Kempf, B. \& Bremer, E. Uptake and synthesis of compatible solutes as microbial stress responses to high-osmolality environments. Arch. Microbiol. 170, 319-330 (1998).

56. Hoffmann, T. \& Bremer, E. Guardians in a stressful world: the Opu family of compatible solute transporters from Bacillus subtilis. Biol. Chem. 398, 193-214 (2017).

57. Hippe, H., Caspari, D., Fiebig, K. \& Gottschalk, G. Utilization of trimethylamine and other N-methyl compounds for growth and methane formation by Methanosarcina barkeri. Proc. Natl. Acad. Sci. 76, 494-498 (1979).

58. Kreisl, P. \& Kandler, O. Chemical structure of the cell wall polymer of Methanosarcina. Syst. Appl. Microbiol. 7, 293-299 (1986).

59. Jarrell, K. F., Jones, G. M., Kandiba, L., Nair, D. B. \& Eichler, J. S-Layer Glycoproteins and Flagellins: Reporters of Archaeal Posttranslational Modifications. Archaea 2010, 1-13 (2010).

60. Srinivasan, G. Pyrrolysine Encoded by UAG in Archaea: Charging of a UAG-Decoding Specialized tRNA. Science 296, 1459-1462 (2002).

61. Bin, P., Huang, R. \& Zhou, X. Oxidation Resistance of the Sulfur Amino Acids: Methionine and Cysteine. Biomed Res. Int. 2017, 1-6 (2017).

62. Armesto, X. L., Canle L, M., Fernández, M. I., García, M. V. \& Santaballa, J. A. First Steps in the Oxidation of Sulfur-Containing Amino Acids by Hypohalogenation: Very Fast Generation of 
Intermediate Sulfenyl Halides and Halosulfonium Cations. Tetrahedron 56, 1103-1109 (2000).

63. Casanueva, A., Tuffin, M., Cary, C. \& Cowan, D. A. Molecular adaptations to psychrophily: the impact of 'omic' technologies. Trends Microbiol. 18, 374-381 (2010).

64. Oren, A. Formation and breakdown of glycine betaine and trimethylamine in hypersaline environments. Antonie Van Leeuwenhoek 58, 291-298 (1990).

65. Seibel, B. A. \& Walsh, P. J. Trimethylamine oxide accumulation in marine animals: relationship to acylglycerol storage. J. Exp. Biol. 205, 297-306 (2002).

66. Lobo, A. L. \& Zinder, S. H. Nitrogen fixation by methanogenic bacteria. in Biological Nitrogen Fixation (eds. Stacey, G., Burris, R. H. \& Evans, H. J.) 191-211 (Chapman and Hall, 1992).

67. Sohm, J. A., Webb, E. A. \& Capone, D. G. Emerging patterns of marine nitrogen fixation. Nat. Rev. Microbiol. 9, 499-508 (2011).

68. Coates, J. D. \& Achenbach, L. A. Microbial perchlorate reduction: rocket-fuelled metabolism. Nat. Rev. Microbiol. 2, 569-580 (2004).

69. Bardiya, N. \& Bae, J.-H. Dissimilatory perchlorate reduction: A review. Microbiol. Res. 166, 237-254 (2011).

70. Barnum, T. P. et al. Genome-resolved metagenomics identifies genetic mobility, metabolic interactions, and unexpected diversity in perchlorate-reducing communities. ISME J. 12, 1568-1581 (2018).

71. Oren, A., Elevi Bardavid, R. \& Mana, L. Perchlorate and halophilic prokaryotes: implications for possible halophilic life on Mars. Extremophiles 18, 75-80 (2014).

72. Liebensteiner, M. G., Pinkse, M. W. H., Schaap, P. J., Stams, A. J. M. \& Lomans, B. P. Archaeal (Per)Chlorate Reduction at High Temperature: An Interplay of Biotic and Abiotic Reactions. Science 340, 85-87 (2013).

73. Bender, K. S. et al. Identification, Characterization, and Classification of Genes Encoding Perchlorate Reductase. J. Bacteriol. 187, 5090-5096 (2005).

74. Youngblut, M. D. et al. Perchlorate Reductase Is Distinguished by Active Site Aromatic Gate Residues. J. Biol. Chem. 291, 9190-9202 (2016).

75. Okeke, B. C., Giblin, T. \& Frankenberger, W. T. Reduction of perchlorate and nitrate by salt tolerant bacteria. Environ. Pollut. (2002) doi:10.1016/S0269-7491(01)00288-3.

76. He, L. et al. Biological perchlorate reduction: which electron donor we can choose? Environ. Sci. Pollut. Res. 26, 16906-16922 (2019).

77. Xie, T. et al. Perchlorate bioreduction linked to methane oxidation in a membrane biofilm reactor: Performance and microbial community structure. J. Hazard. Mater. (2018) doi:10.1016/j.jhazmat.2018.06.011.

78. Chaudhuri, S. K., O’Connor, S. M., Gustavson, R. L., Achenbach, L. A. \& Coates, J. D. Environmental factors that control microbial perchlorate reduction. Appl. Environ. Microbiol. (2002) doi:10.1128/AEM.68.9.4425-4430.2002. 
79. Abu-Omar, M. M. Effective and Catalytic Reduction of Perchlorate by Atom Transfer-Reaction Kinetics and Mechanisms. Comments Inorg. Chem. 24, 15-37 (2003).

80. Adkins, H. \& Cramer, H. I. THE USE OF NICKEL AS A CATALYST FOR HYDROGENATION. J. Am. Chem. Soc. 52, 4349-4358 (1930).

81. Thauer, R. K. et al. Hydrogenases from Methanogenic Archaea, Nickel, a Novel Cofactor, and $\mathrm{H} 2$ Storage. Annu. Rev. Biochem. 79, 507-536 (2010).

82. Zhang, H., Bruns, M. A. \& Logan, B. E. Perchlorate reduction by a novel chemolithoautotrophic, hydrogen-oxidizing bacterium. Environ. Microbiol. (2002) doi:10.1046/j.1462-2920.2002.00338.x.

83. Ide, T., Bäumer, S. \& Deppenmeier, U. Energy Conservation by the H2:Heterodisulfide Oxidoreductase from Methanosarcina mazei Gö1: Identification of Two Proton-Translocating Segments. J. Bacteriol. 181, 4076-4080 (1999).

84. Deppenmeier, U. The Membrane-Bound Electron Transport System of Methanosarcina Species. J. Bioenerg. Biomembr. 36, 55-64 (2004).

85. Meuer, J., Kuettner, H. C., Zhang, J. K., Hedderich, R. \& Metcalf, W. W. Genetic analysis of the archaeon Methanosarcina barkeri Fusaro reveals a central role for Ech hydrogenase and ferredoxin in methanogenesis and carbon fixation. Proc. Natl. Acad. Sci. 99, 5632-5637 (2002).

86. Kulkarni, G., Mand, T. D. \& Metcalf, W. W. Energy Conservation via Hydrogen Cycling in the Methanogenic Archaeon Methanosarcina barkeri. MBio 9, (2018).

87. Bobik, T. Formyl-methanofuran synthesis in Methanobacterium thermoautotrophicum. FEMS Microbiol. Lett. 87, 323-326 (1990).

88. Wang, D. M., Shah, S. I., Chen, J. G. \& Huang, C. P. Catalytic reduction of perchlorate by H2 gas in dilute aqueous solutions. Sep. Purif. Technol. 60, 14-21 (2008).

89. Thauer, R. K., Kaster, A.-K., Seedorf, H., Buckel, W. \& Hedderich, R. Methanogenic archaea: ecologically relevant differences in energy conservation. Nat. Rev. Microbiol. 6, 579-591 (2008).

90. Mand, T. D. \& Metcalf, W. W. Energy Conservation and Hydrogenase Function in Methanogenic Archaea, in Particular the Genus Methanosarcina. Microbiol. Mol. Biol. Rev. 83, (2019).

91. Rummel, J. D. et al. A New Analysis of Mars "Special Regions": Findings of the Second MEPAG Special Regions Science Analysis Group (SR-SAG2). Astrobiology 14, 887-968 (2014).

92. Bryant, M. P. \& Boone, D. R. Emended Description of Strain MST(DSM 800T), the Type Strain of Methanosarcina barkeri. International Journal of Systematic Bacteriology vol. 37 169-170 (1987).

93. Widdel, F., Kohring, G.-W. \& Mayer, F. Studies on dissimilatory sulfate-reducing bacteria that decompose fatty acids. Arch. Microbiol. 134, 286-294 (1983).

94. Francisco, D. E., Mah, R. A. \& Rabin, A. C. Acridine Orange-Epifluorescence Technique for Counting Bacteria in Natural Waters. Trans. Am. Microsc. Soc. 92, 416 (1973).

95. Chen, S., Zhou, Y., Chen, Y. \& Gu, J. fastp: an ultra-fast all-in-one FASTQ preprocessor. Bioinformatics 34, i884-i890 (2018). 
96. Langmead, B. \& Salzberg, S. L. Fast gapped-read alignment with Bowtie 2. Nat. Methods 9, 357-9 (2012).

97. Li, H. et al. The Sequence Alignment/Map format and SAMtools. Bioinformatics 25, 2078-2079 (2009).

98. Quinlan, A. R. \& Hall, I. M. BEDTools: a flexible suite of utilities for comparing genomic features. Bioinformatics 26, 841-842 (2010).

99. Camacho, C. et al. BLAST+: architecture and applications. BMC Bioinformatics 10, 421 (2009).

100. Love, M., Anders, S. \& Huber, W. Differential analysis of count data-the DESeq2 package. Genome Biol. 15, 10-1186 (2014).

101. Ogata, H. et al. KEGG: Kyoto Encyclopedia of Genes and Genomes. Nucleic Acids Res. 27, 29-34 (1999).

\section{Tables}

Tables 1 and 2 are available in the Supplementary Files

\section{Figures}




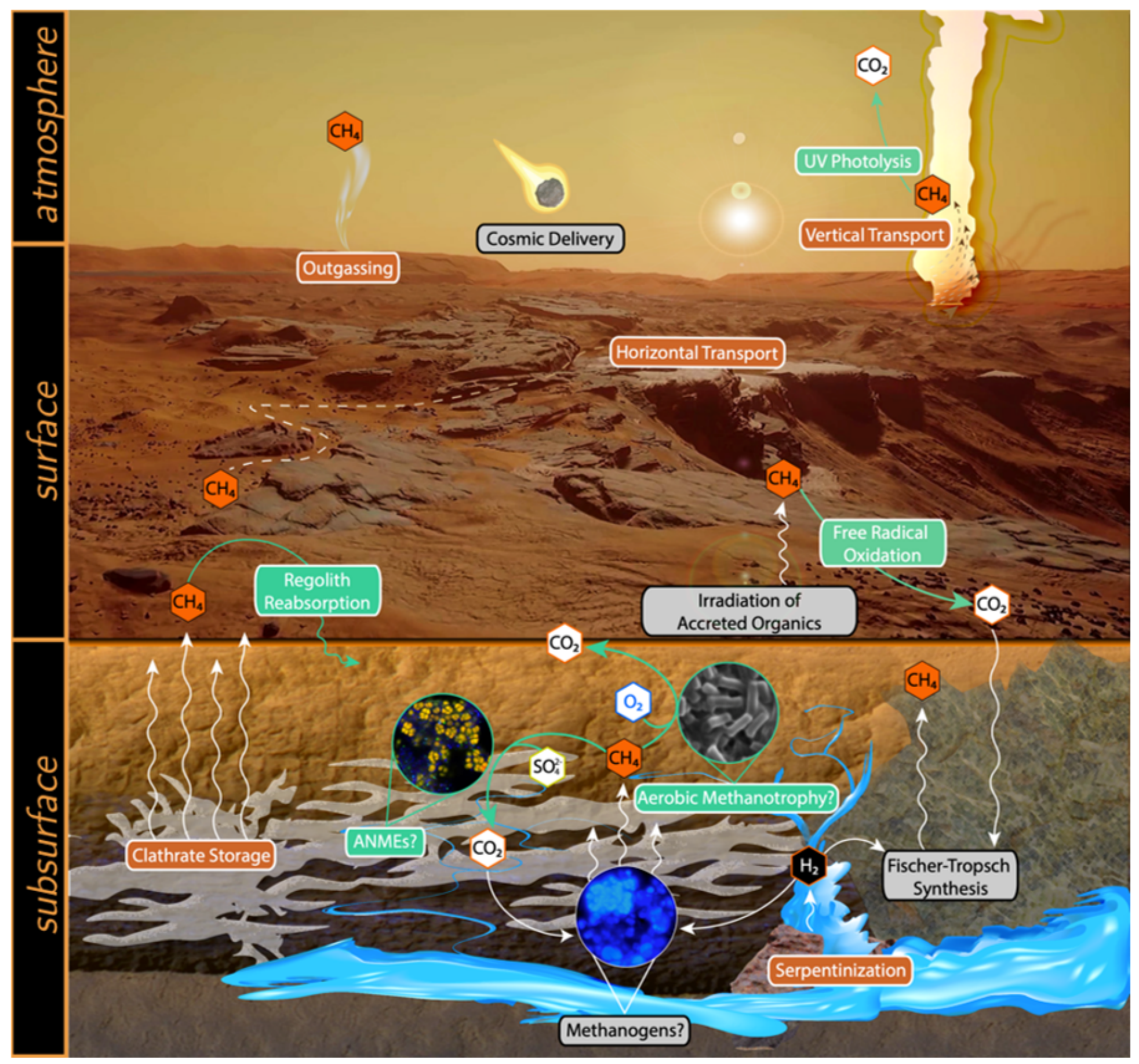

\section{Figure 1}

Proposed model for Martian $\mathrm{CH} 4$ cycle. Sources indicated by grey boxes. Sinks are highlighted by green boxes and accompanying arrows10,101-103. Reservoirs, transport systems, and substrate-generating intermediates are denoted by orange boxes. This figure was generated using images from Mars Reconnaissance Orbiter and Mars 2030 virtual reality game (produced by NASA in collaboration with the MIT AeroAstro Lab and Fusion Media Group, Doral FL) in accordance with the fair use doctrine of United States copyright law. Abbreviations: ANMEs, anaerobic methanotrophs. 


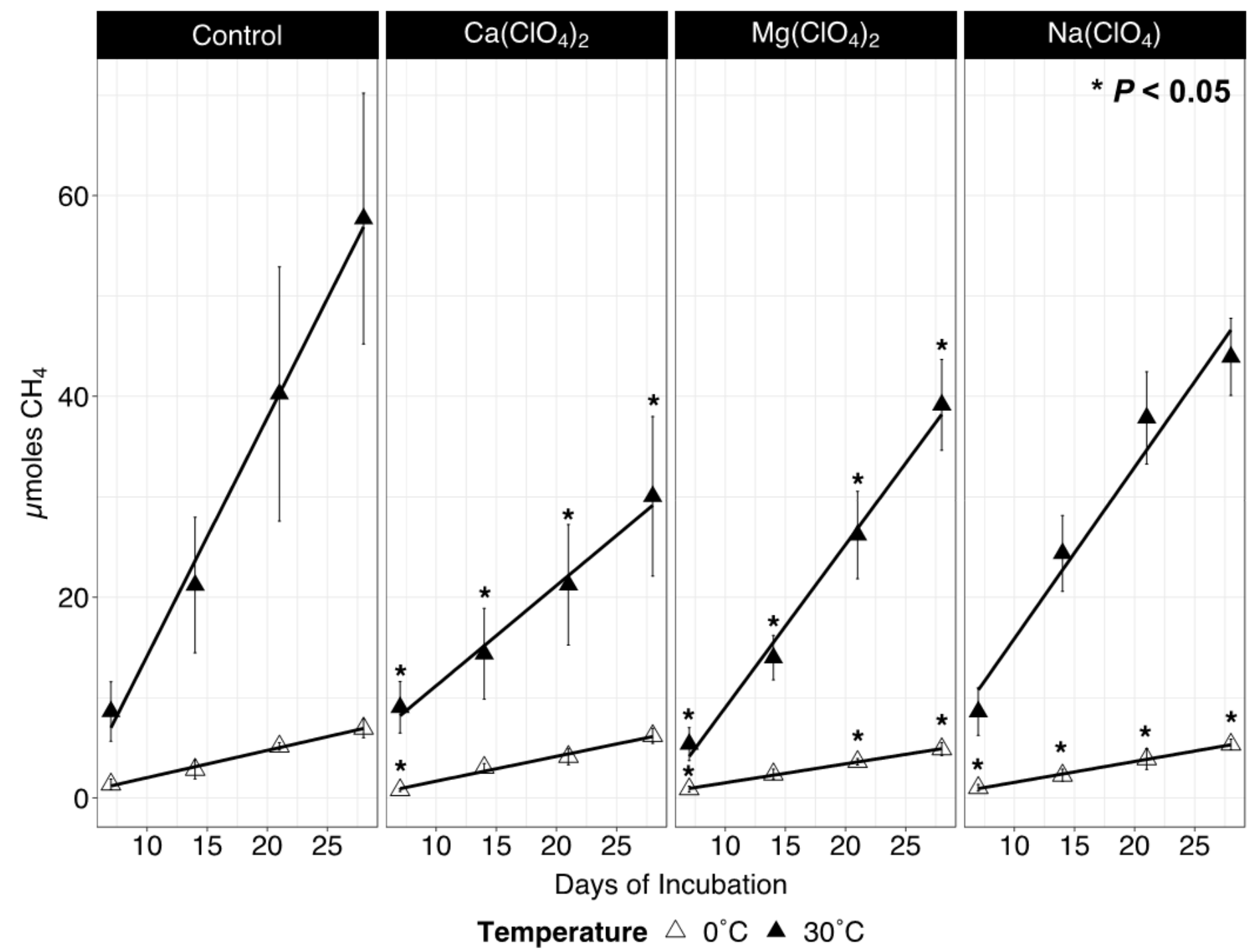

Figure 2

Cumulative $\mathrm{CH} 4$ production by $\mathrm{M}$. barkeri strain $\mathrm{MS}$ (from left to right) in media without perchlorate (Control), $\mathrm{Ca}(\mathrm{ClO} 4), \mathrm{Mg}(\mathrm{ClO} 4) 2$, or $\mathrm{Na}(\mathrm{ClO} 4)$ at $30^{\circ} \mathrm{C}$ (filled triangles) and $0^{\circ} \mathrm{C}$ (open triangles). Statistically significant differences in $\mathrm{CH} 4$ production in perchlorate-supplemented incubations relative to the control of the same temperature are indicated by asterisks $\left(^{*}\right)$ (paired t-test, $P<0.05$ ). 


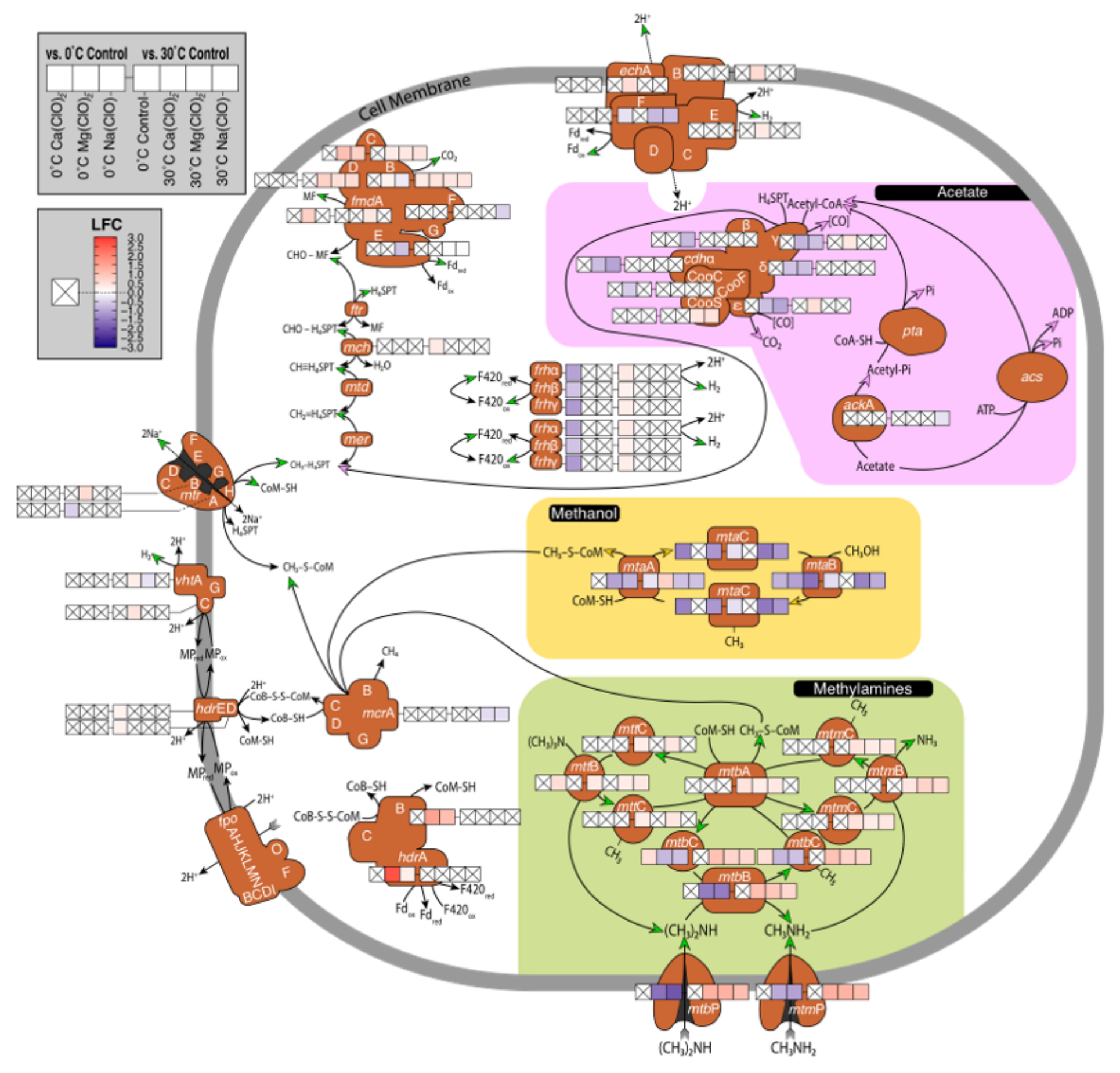

\section{Figure 3}

Statistically significant differential expression (Log2-fold change, LFC; Wald test, $\mathrm{P}<0.05$ ) of methanogenesis genes in M. barkeri strain MS. Differential expression of each gene across 7 assessed conditions is indicated via heatmap. Averages are presented for multi-copy genes (for exact values, reference Tables 1 and 2). Differential expression of genes in $0^{\circ} \mathrm{C}$ perchlorate-amended transcriptomes are relative to the expression patterns of the $0^{\circ} \mathrm{C}$ perchlorate-free control. Perchlorate-amended $30^{\circ} \mathrm{C}$ and $0^{\circ} \mathrm{C}$ perchlorate-free control transcriptomes are relative to the expression patterns of the $30^{\circ} \mathrm{C}$ perchloratefree control. Crossed white boxes indicate no statistically significant difference in expression. Heatmaps 
are excluded from genes exhibiting no significant differential expression across all conditions. Genes involved in non-hydrogenotrophic $(\mathrm{H} 2 / \mathrm{CO} 2)$ pathways are encompassed in colored boxes with pathway directionality indicated by matching arrowheads (green: methylamines; pink: acetate; yellow: methanol). Full names of listed genes and metabolites are found in Tables S12 and S13, respectively.

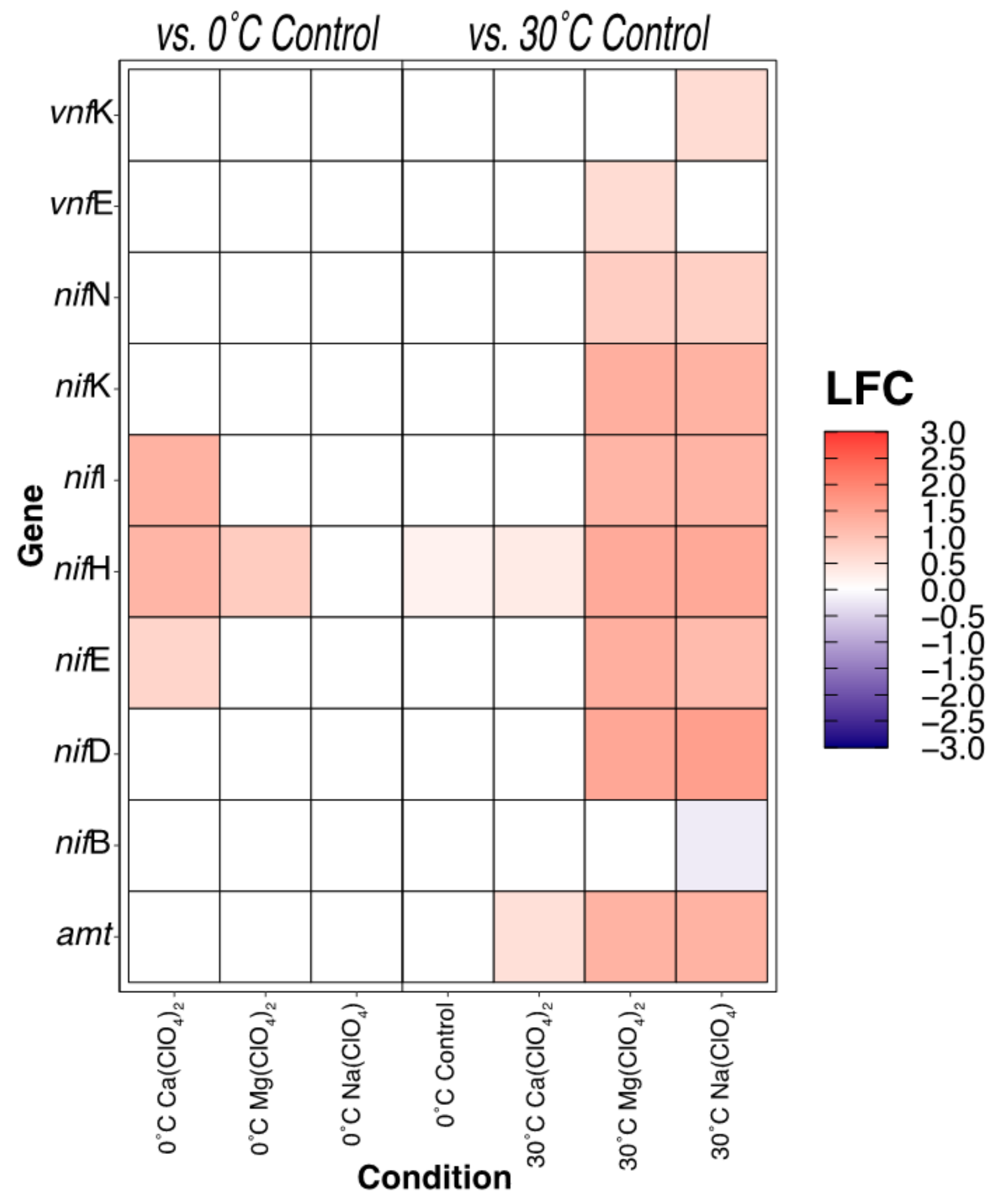

Figure 4 
Differential expression (Log2-fold change, LFC) of ammonium transporters (amt), Mo-containing nitrogenase (nif), and V-containing nitrogenase genes in M. barkeri MS. Perchlorate-amended $30^{\circ} \mathrm{C}$ and $0^{\circ} \mathrm{C}$ perchlorate-free control cultures are relative to $30^{\circ} \mathrm{C}$ perchlorate-free control. $0^{\circ} \mathrm{C}$ perchlorate-amended cultures are relative to $0^{\circ} \mathrm{C}$ perchlorate-free control. Significance identified via Wald test $(P<0.05)$. Full names of proteins encoded by listed genes are found in Tables S14.

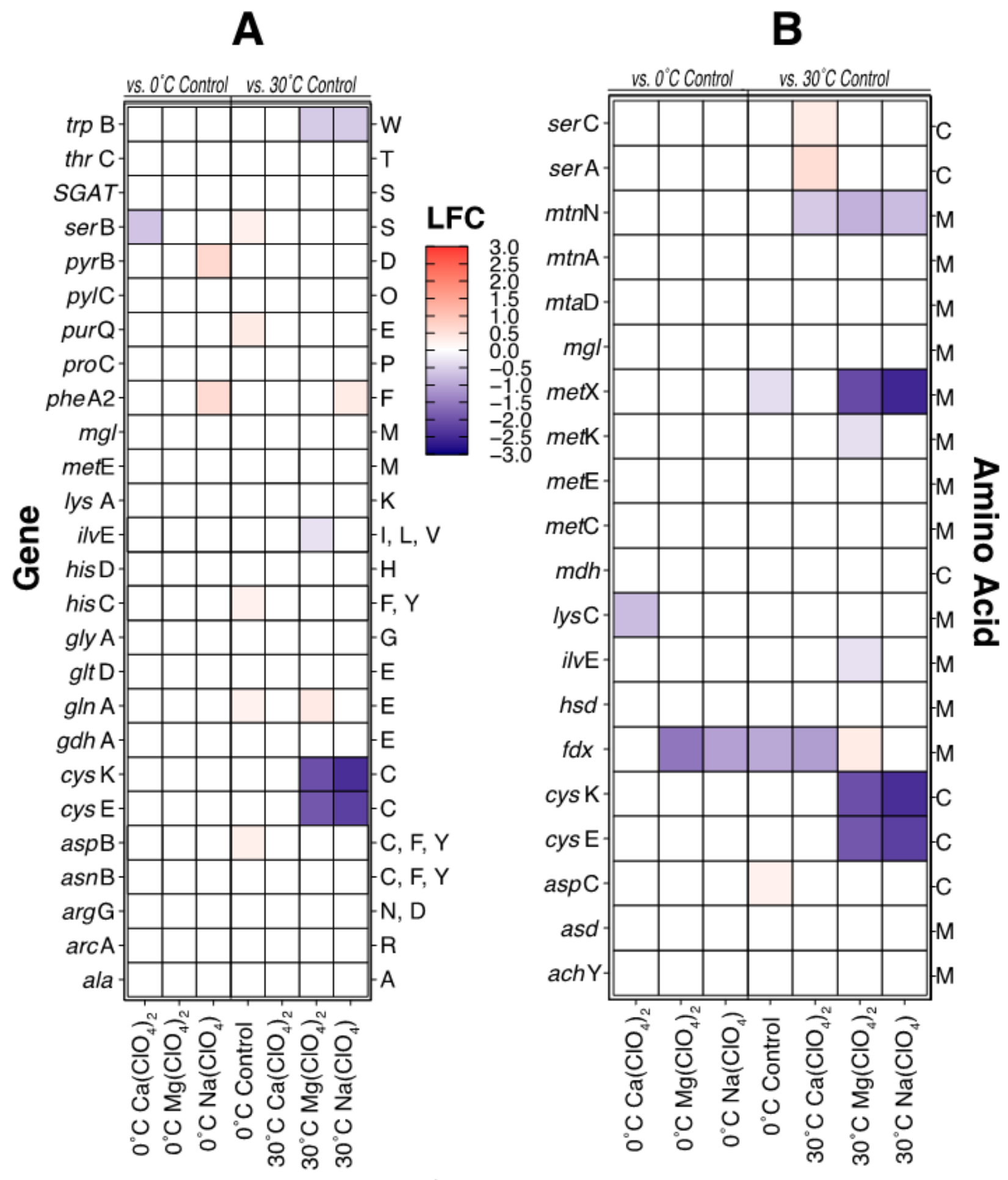

Condition

Figure 5 
Differential expression (Log2-fold change, LFC) of genes involved in (a) amino acid synthesis and (b) recycling of the sulfur-containing amino acids methionine and cysteine in M. barkeri MS. Perchlorateamended $30^{\circ} \mathrm{C}$ and $0^{\circ} \mathrm{C}$ perchlorate-free control cultures are relative to $30^{\circ} \mathrm{C}$ perchlorate-free control. $0^{\circ} \mathrm{C}$ perchlorate-amended cultures are relative to $0^{\circ} \mathrm{C}$ perchlorate-free control. Full names of gene and amino acid abbreviations are respectively found in Tables S15 and S16.

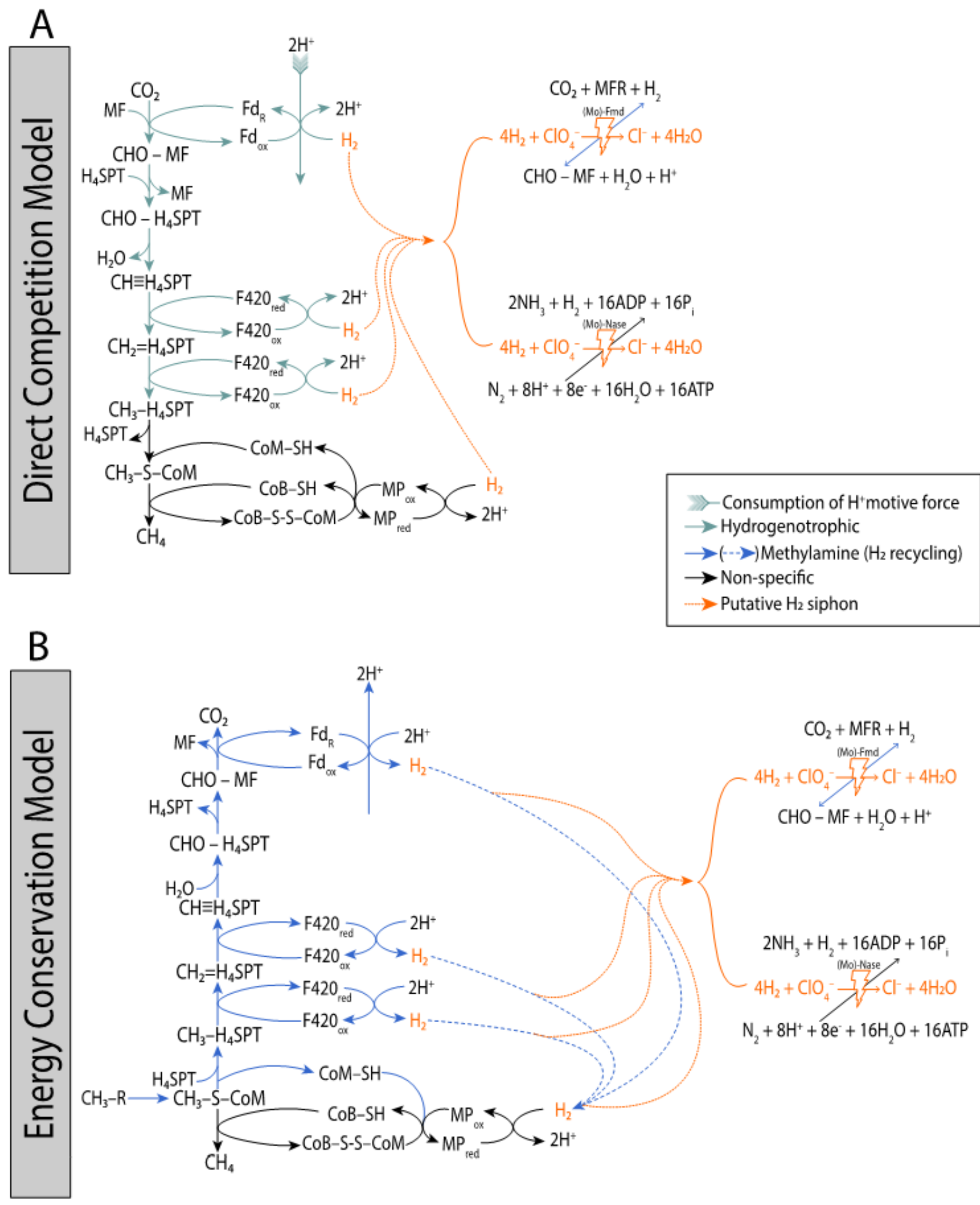

Figure 6 
Proposed models of Mo- and H2-dependent perchlorate reduction occurring a) in direct competition with hydrogenotrophic methanogenesis, and $b$ ) via the energy-conserving partial reversal of methylaminebased methanogenesis. Abbreviations: Non-specific, common to multiple pathways; MF, methanofuran; CHO-MF, formyl-methanofuran; H4SPT, tetrahydrosarcinapterin; CHO-H4SPT, formyl-

tetrahydrosarcinapterin; $\mathrm{CH} \equiv \mathrm{H} 4 \mathrm{SPT}$, methenyl-tetrahydrosarcinapterin; $\mathrm{CH} 2=\mathrm{H} 4 \mathrm{SPT}$, methylenetetrahydrosarcinapterin; $\mathrm{CH} 3-\mathrm{H} 4 \mathrm{SPT}$, methyl-tetrahydrosarcinapterin; $\mathrm{CoM}-\mathrm{SH}$, coenzyme M; CoB-SH, coenzyme B; CoB-S-S-CoM, CoB-CoM heterodisulphide; CH3-S-CoM, methyl-coenzyme M; CH3-R, methylamine; MP, methanophenazine; Fd, ferredoxin; F420, coenzyme F420; (Mo)-Fmd, (Mo)formylmethanofuran dehydrogenase; (Mo)-Nase, (Mo)-nitrogenase.

\section{Supplementary Files}

This is a list of supplementary files associated with this preprint. Click to download.

- Table1.xlsx

- Table2.xlsx

- SUPPLEMENTARYINFORMATIONMartiantranscriptomicsFINAL.docx

- TableS2.xlsx

- TablesS5S11sig.differentialexpression.xlsx 